\title{
REVIEW
}

\section{Tumors and tumor like lesions of the patella - Pictorial essay Subbarao Kakarla ${ }^{1, *}$ \\ ${ }^{1}$ KIMS Foundation and Research Centre, Minister Road, Secunderabad - 500003, Telangana, India}

\begin{abstract}
Focal lesions of patella are not infrequent. The patella is an uncommon location for neoplasms. The majority of tumors of the patella are benign, with a significant incidence of chondroblastoma and giant cell tumor. Other lesions include aneurysmal bone cysts, osteoid osteoma and osteoblastoma. In our experience chondroblastoma is the most common benign tumor. Malignant tumors include osteosarcoma, lymphosarcoma and metastasis. Radiological features are similar to the lesions at other sites except periosteal reaction is uncommon. However, tumor like lesions often pose a difficult problem in ruling out a real neoplasm which is important in order to avoid a biopsy. These include developmental, traumatic, infective, metabolic and endocrinal entities. Miscellaneous lesions include Paget disease and degenerative joint disease. Radiologically, it is important to identify the tumor like lesions and to differentiate them from primary neoplasms. Advanced imaging is rarely necessary, but histological confirmation is mandatory.
\end{abstract}

Keywords: Benign; malignant tumors; patella; tumor like lesions; gout; brown tumor; Paget's

*Corresponding author: Prof. Kakarla Subbarao, MS, D.Sc. (HON), FRCR, FACR, FICP, FSASMA, FCCP, FICR, FCGP, Chairman, KIMS Foundation and Research Centre, Minister Road, Secunderabad 500003, Telangana, India. Email: subbaraokakarla25@gmail.com

Received 12 July 2018; Revised 24 August 2018; Accepted 5 September 2018; Published 11 September 2018

Citation: Kakarla S. Tumors and tumor like lesions of the patella - Pictorial essay. J Med Sci Res. 2018; 6(4):103-116. DOI: http:// dx.doi.org/10.17727/JMSR.2018/6-19

Copyright: @ 2018 Kakarla S et al. Published by KIMS Foundation and Research Center. This is an open-access article distributed under the terms of the Creative Commons Attribution License, which permits unrestricted use, distribution, and reproduction in any medium, provided the original author and source are credited.

\section{Introduction}

Patella is the largest sesamoid in the quadriceps tendon. Although fractures of the patella are more common, tumors and tumor like lesions are not infrequent. The benign tumors such as chondroblastoma, giant cell tumor, aneurysmal bone cyst, osteoid osteoma and osteoblastoma show characteristic radiological patterns [1-4]. Tumor like lesions which include developmental dorsal defect of the patella, post traumatic lesions, osteomyelitis, gout, metabolic and endocrinal disorders reflect on patella [5-9]. Miscellaneous lesions like Paget also should be considered in differential diagnosis. There are very few publications in the radiological literature focusing on patellar lesions. Benign tumors of patella are categorised in Table 1. 
Table 1: Benign tumors of patella.

\begin{tabular}{|ll|}
$>$ & Chondroblastoma \\
$>$ & Giant cell tumor \\
$>$ & Aneurysmal bone cyst \\
$>$ & Osteoid osteoma \\
\hline
\end{tabular}

\section{Radiological characteristics and discussion Chondroblastoma}

It is a rare benign cartilaginous tumor that arises primarily in the epiphysis/ apophysis of a long bone and may extend to the metaphysis. It may occur in small bones of the foot and rarely in the patella. The average age is $1^{\text {st }}$ and $2^{\text {nd }}$ decades with no particular preference to the sex. Radiological characteristics include an expanding lytic lesion arising from the centre of the patella with a lobulated outline with a sclerotic margin [10-12]. No soft tissue swelling is present, unless there is a pathological fracture. It may involve part of the patella or may extend to the entire bone. Punctate type of calcifications may be seen in $1 / 3^{\text {rd }}$ of the patients. MRI shows variable findings (Figure 1).

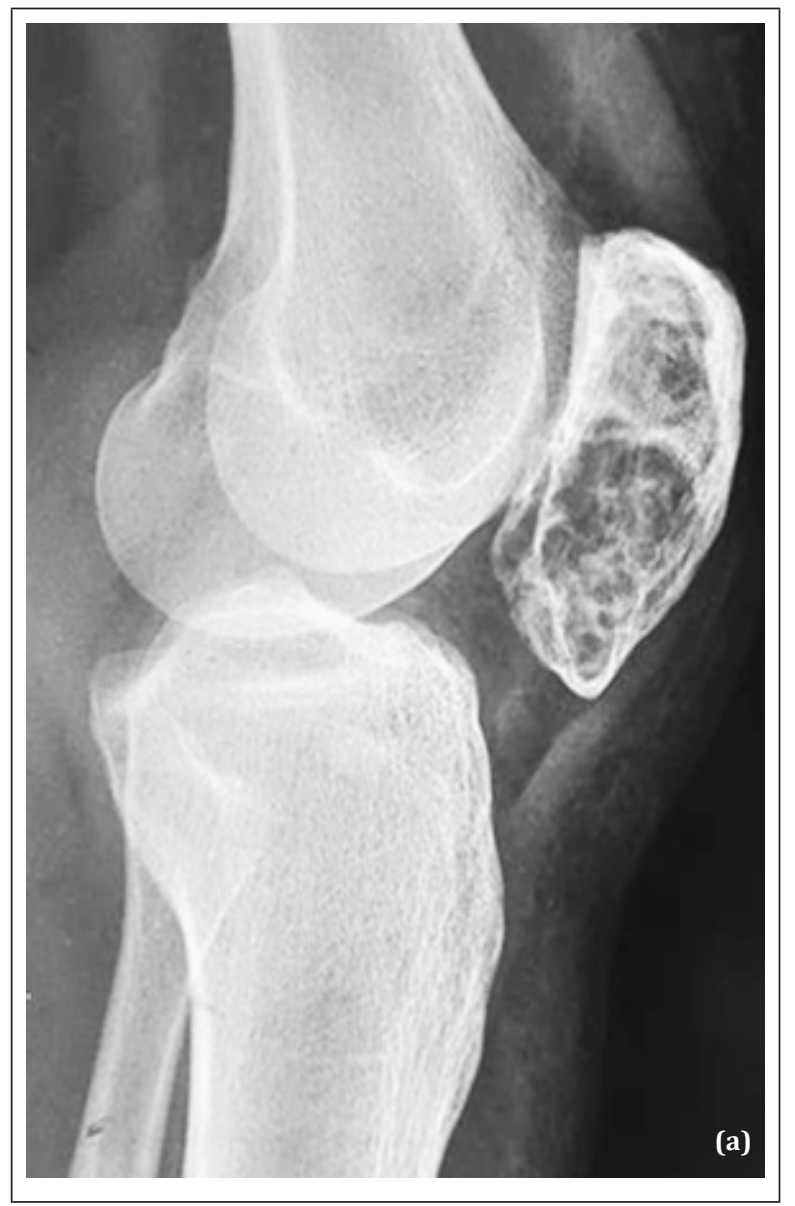

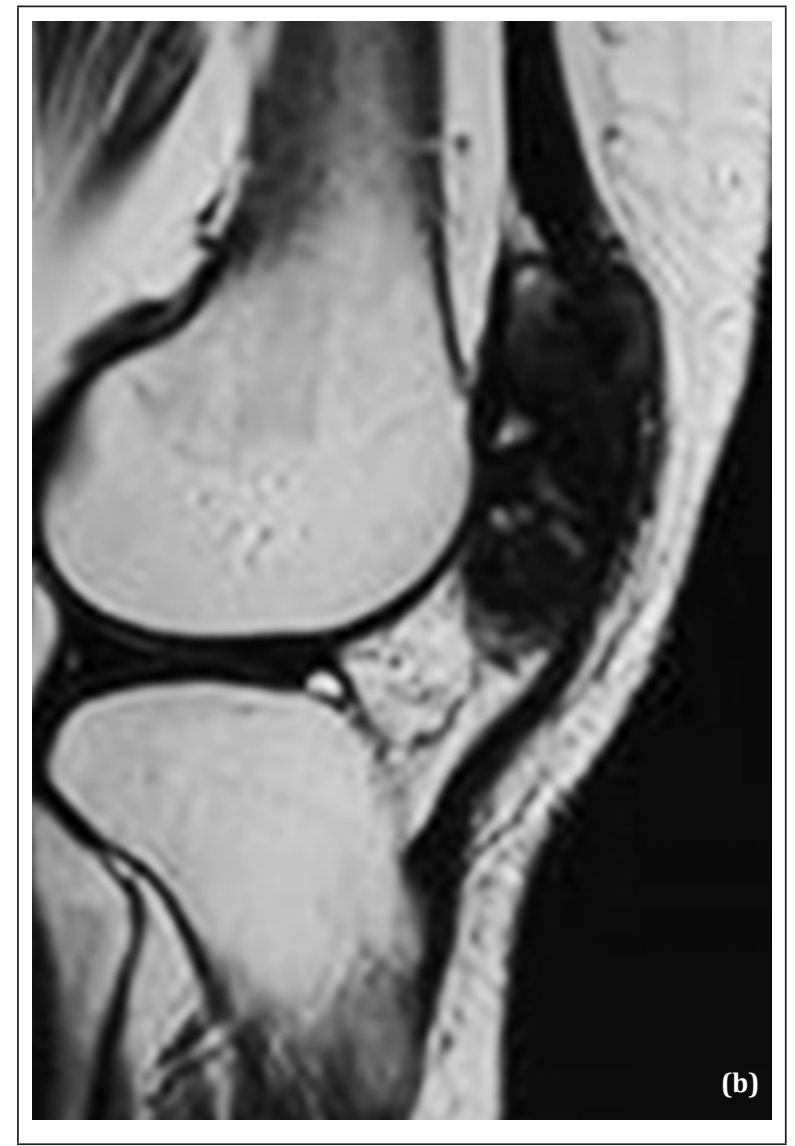

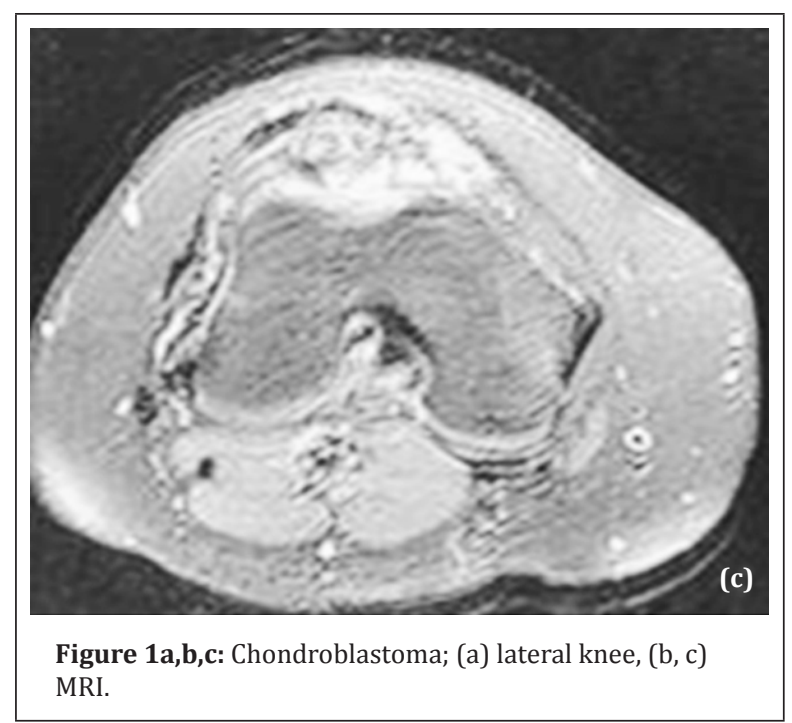

\section{Giant cell tumor}

This tumor generally occurs at the ends of the long bones extending to the articular margin. The average age is between $3^{\text {rd }}$ and $4^{\text {th }}$ decades. Slight predominance is noted in females. Radiologically, an expanding lytic lesion is noted with soap-bubble appearance (Figure 2a, b, c). The lesion extends to the articular margin. Mineralisation of the matrix is 
absent [13-15]. On occasion, the lytic lesions may be completely lucent without any bony trabiculae (Figure 2d, e) simulating aneurysmal bone cyst. On occasion, an aneurysmal bone cyst may be associated, in which instance fluid-fluid levels are noted on MRI.
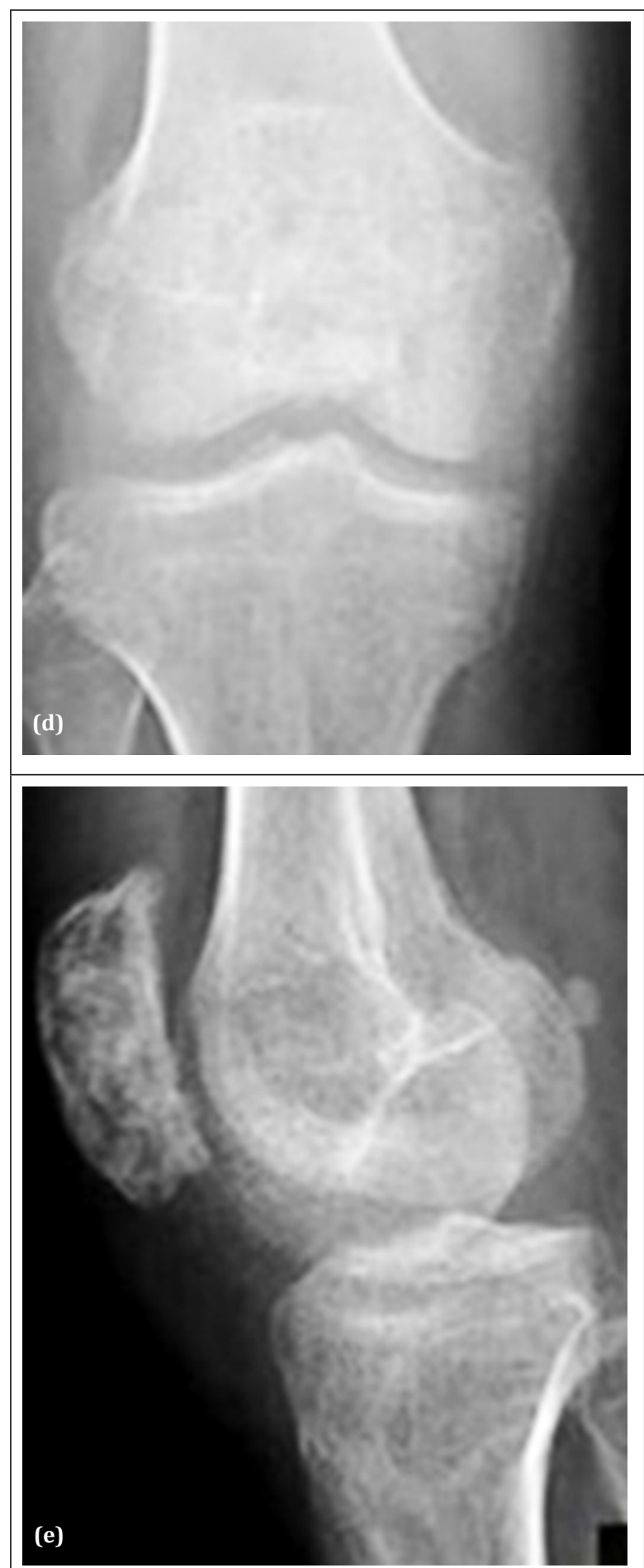

Figure 1d,e: Chondroblastoma; (d) AP view, (e) Lateral.
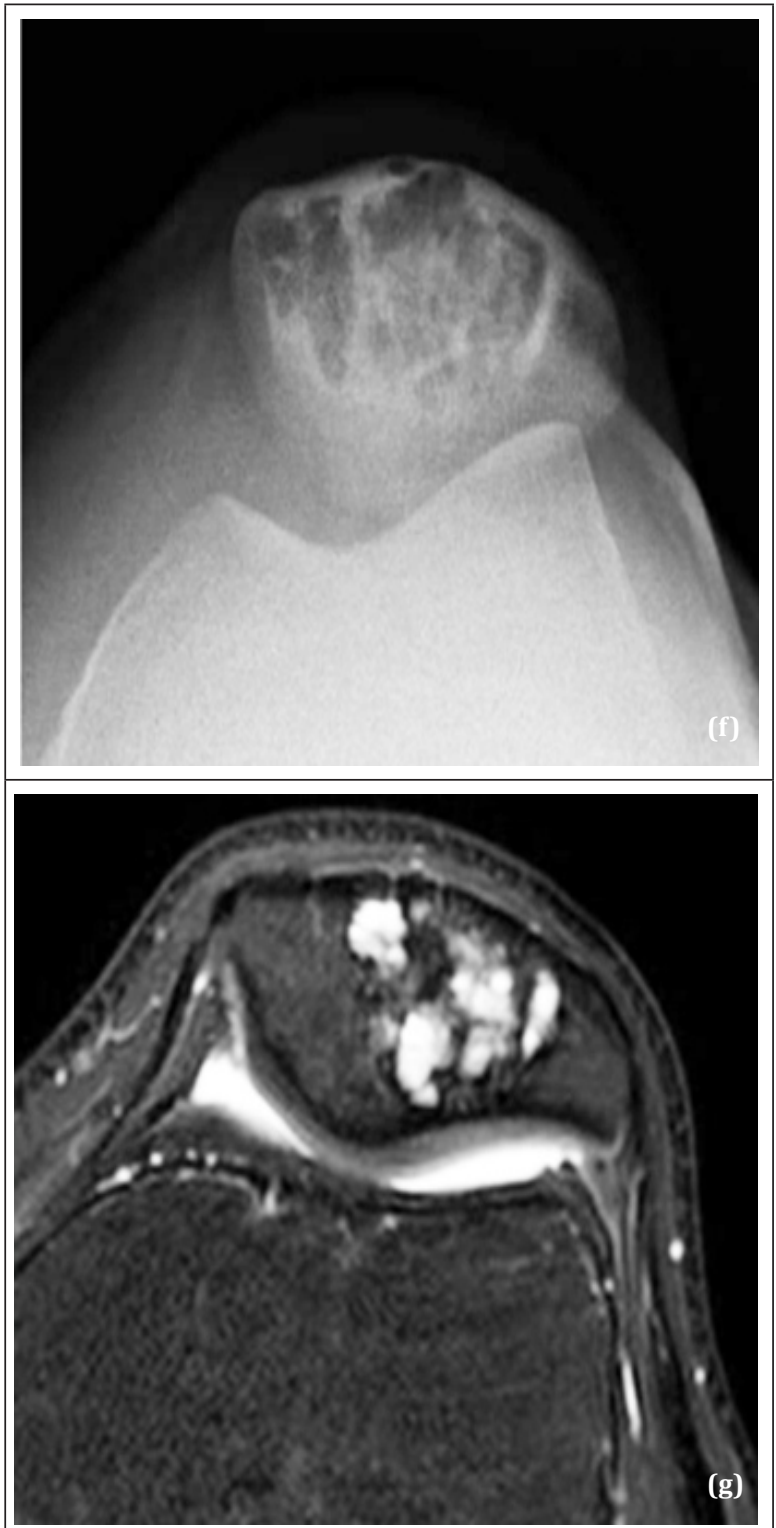

Figure 1f,g: Chondroblastoma; (f) skyline view, (g) MRI.

\section{Aneurysmal bone cyst (ABC)}

This is a benign cystic lesion with multiple blood filled spaces. The matrix is not mineralised. It can be primary or secondary. The etiology is unknown, although in many cases a history of trauma is elicited. The age group extends from $1^{\text {st }}$ to $4^{\text {th }}$ decades. Secondary ABC is associated with many tumors including giant cell tumor, chondroblastoma, osteoblastoma and telangiectatic osteosarcoma. Radiologically, it is an expanding lytic lesion with few trabeculae. It may be segmental or may occupy the entire bone $[16,17]$. MRI shows fluid-fluid levels (Figure 3a, b, c). 

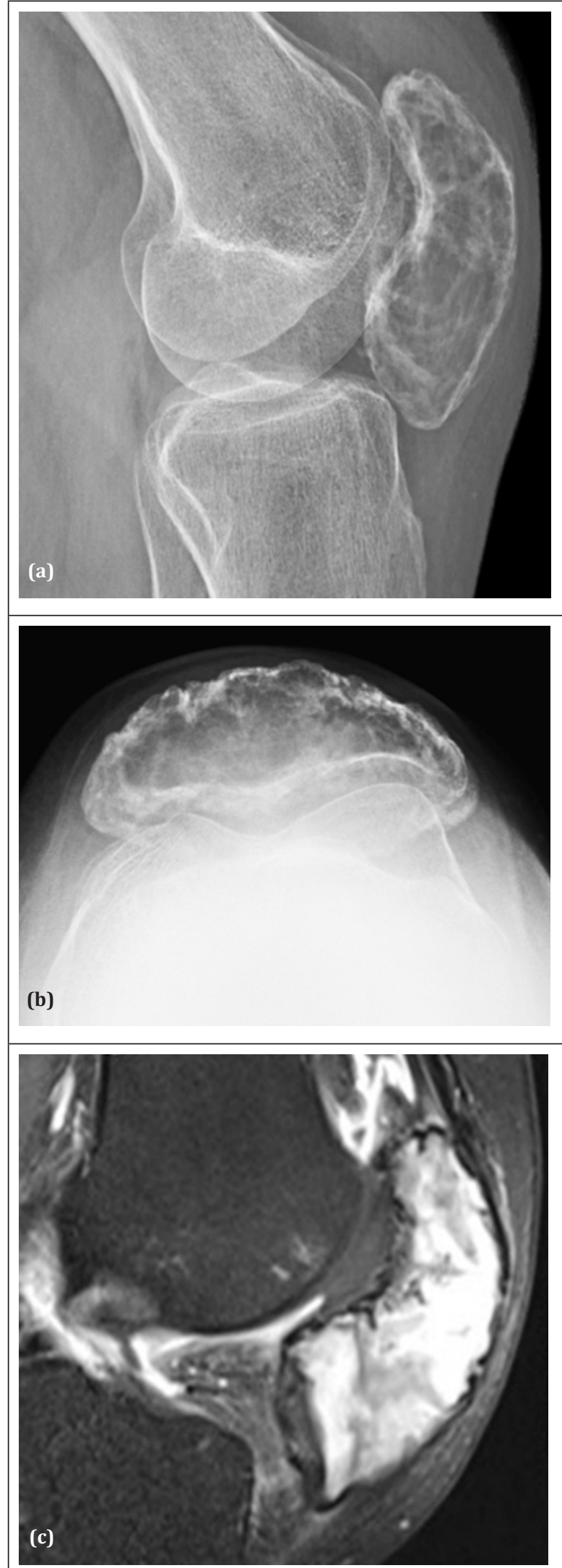

Figure 2a,b,c: Giant cell tumor of the patella; $(a, b)$ plain films, (c) MRI.
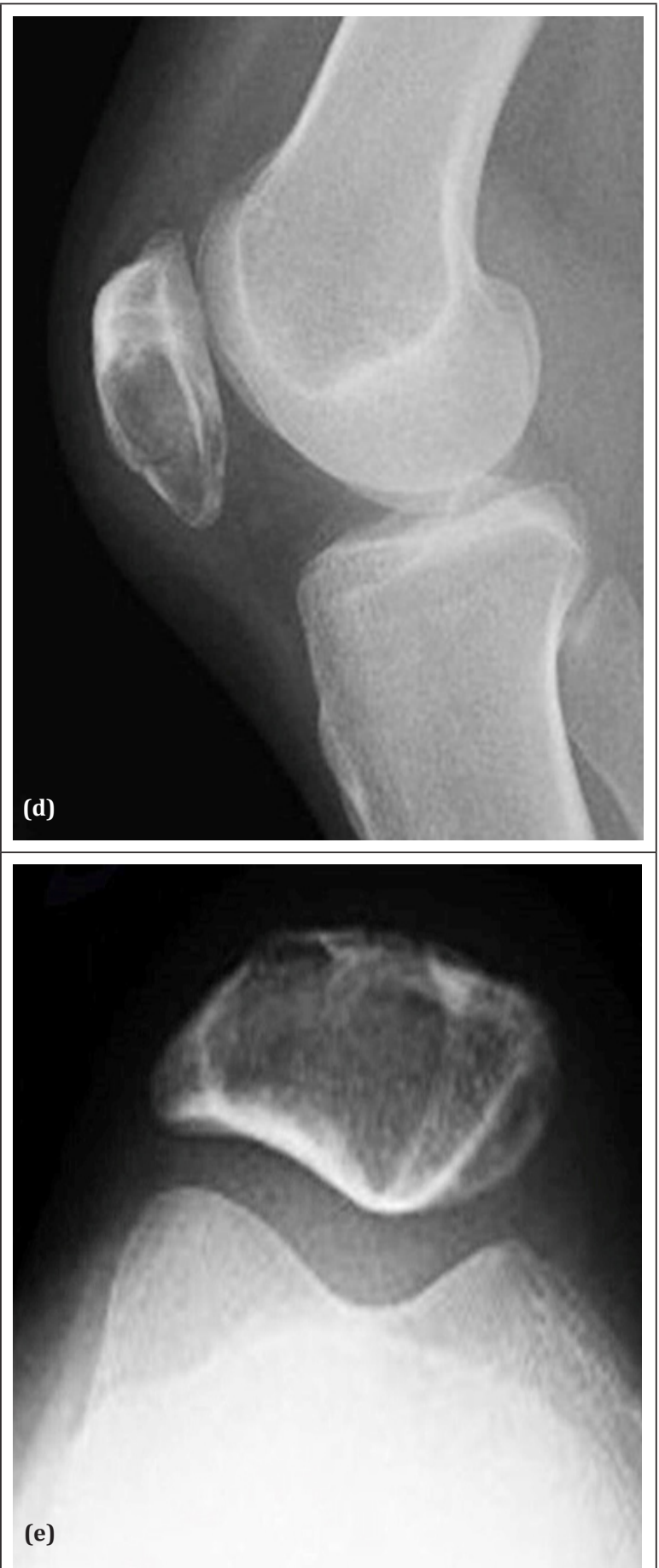

Figure 2d,e: 25 F- Giant cell tumor; (d, e) plain films.

\section{Osteoid osteoma}

It is a benign osseous tumor generally occurring in the younger age group. It may be intracortical, periosteal, trabecular or subarticular. Radiologically, a sclerotic central nidus is noted in a surrounding lucent area (Figure 4). Reactive new bone is often present $[18,19]$. 

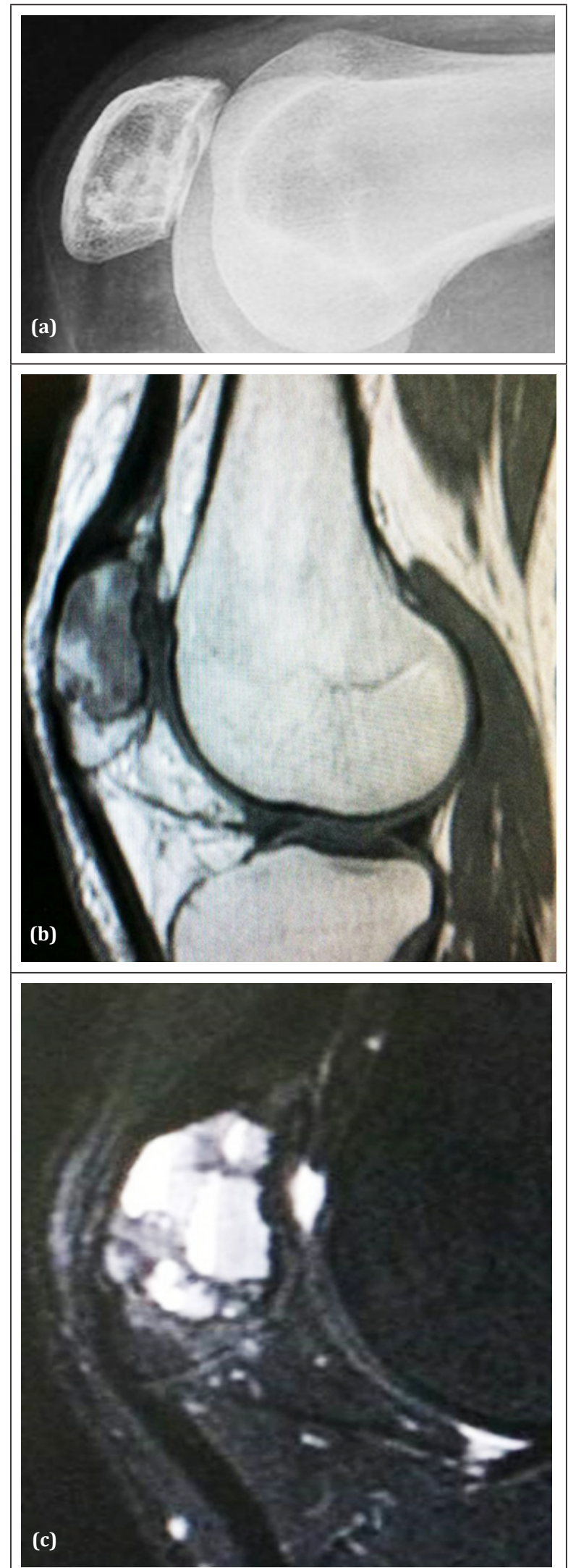

Figure 3a,b,c: Aneurysmal bone cyst; (a) lateral film, (b, c) MRI.

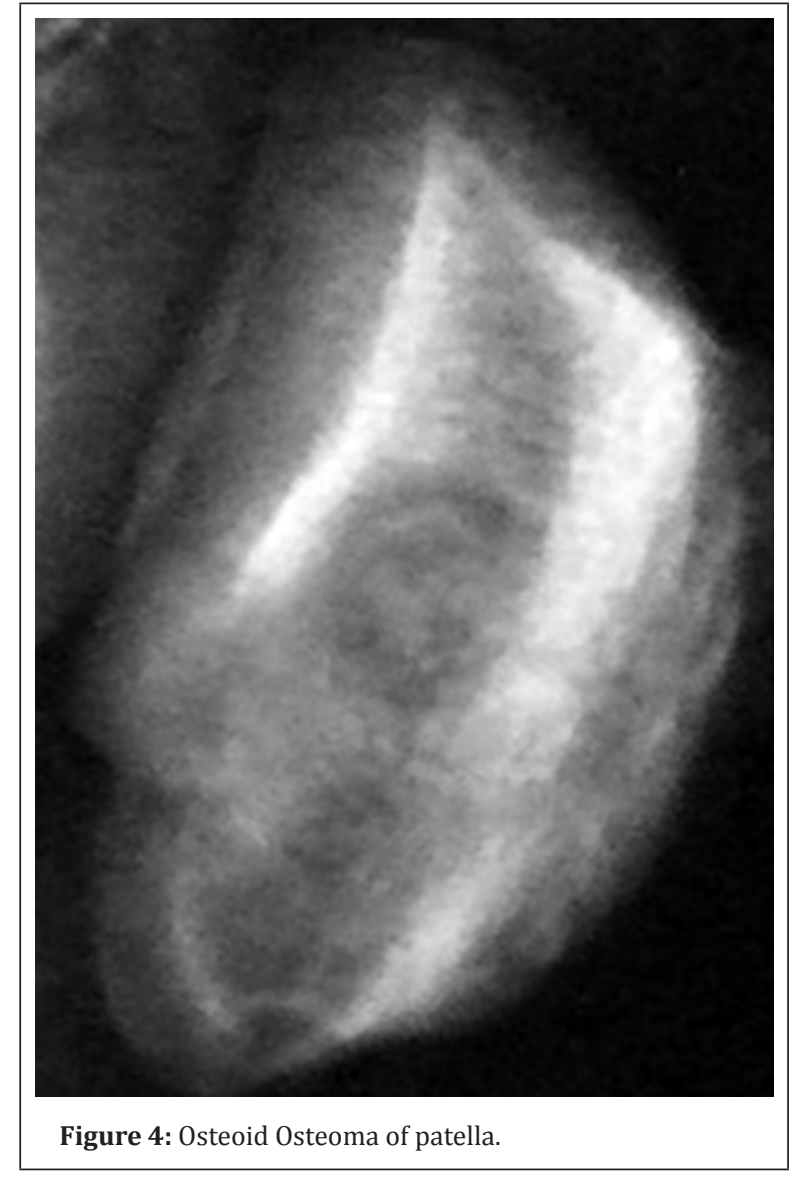

\section{Osteoblastoma}

It is a benign bone producing tumor similar to osteoid osteoma. However, the central nidus is more than $2 \mathrm{cms}$ in diameter and hence called giant osteoid osteoma. The morphology is variable with sclerotic areas in and around the lesion. It is very rare in the patella [20].

Primary malignant tumors: Osteosarcoma, Lymphosarcoma.

\section{Secondary: Metastasis.}

\section{Osteosarcoma}

Morphologically and histologically several types have been described. In patella the most common morphological type is osteoblastic osteosarcoma. It is commonly encountered between the ages of $2^{\text {nd }}$ and $3^{\text {rd }}$ decades. There is no sex preference. In the long bones the metaphysis is primary site. Extensive neoplastic bone is noted in the form of clouds in the matrix extending in to soft tissues (Figure 5a). Both lytic and sclerotic lesions may be noted at the 
same site (Figure 5b, c, d). Periosteal reaction is not observed in the patella [21].

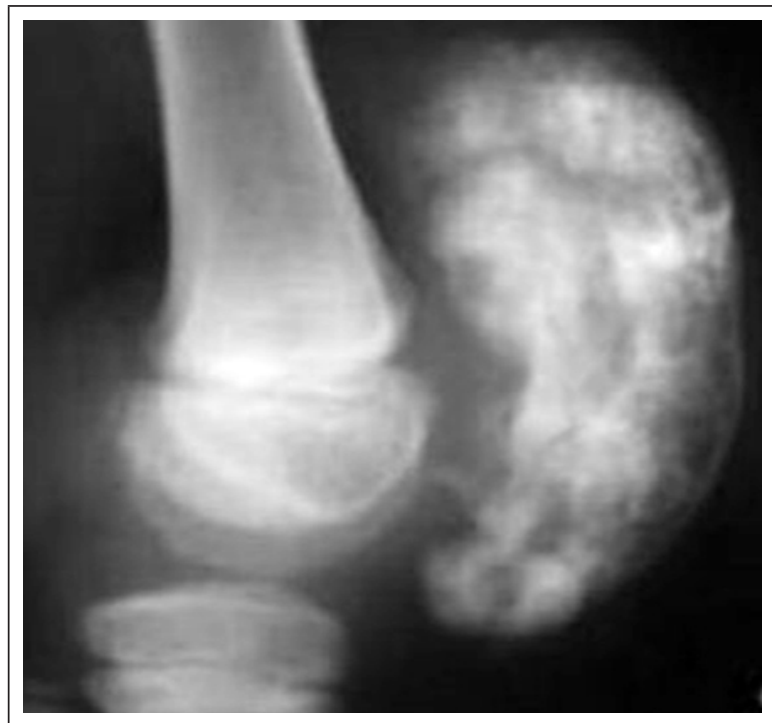

Figure 5a: Osteosarcoma of patella (note the cloud like new bone formation).
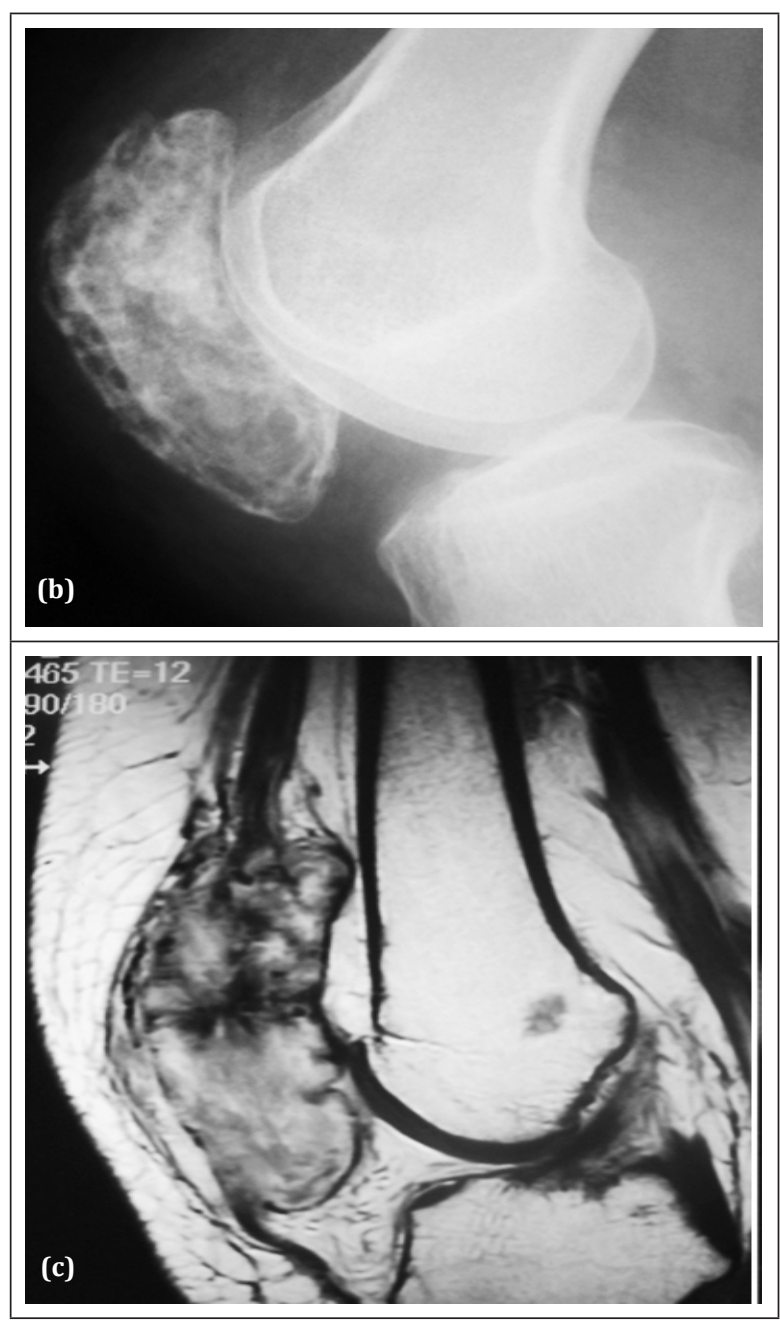

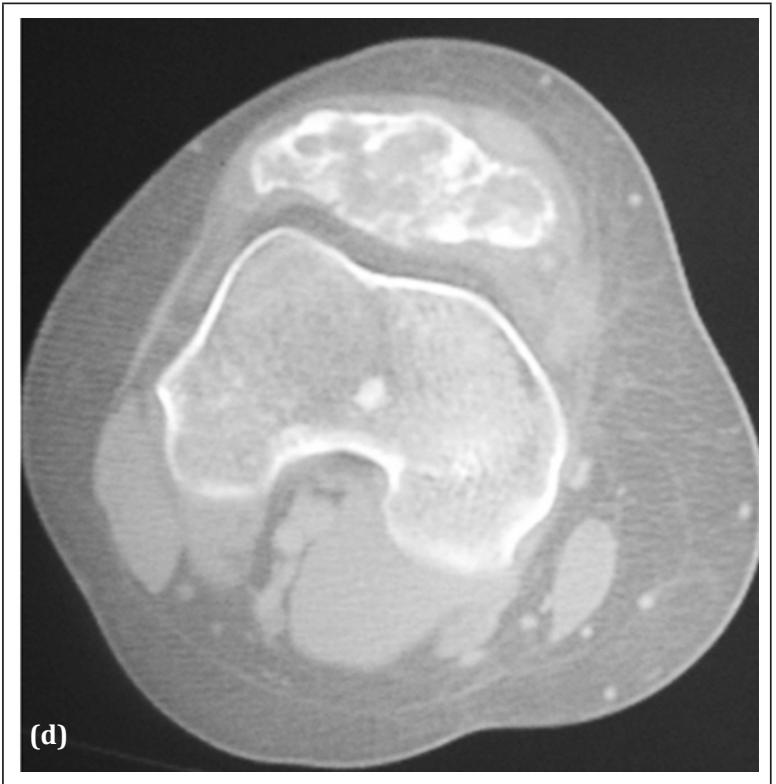

Figure 5b,c,d: Osteosarcoma of the patella.

Lymphoma may be Hodgkin's or non-Hodgkin's. Primary lymphoma of the bone is quite rare and involvement of the patella is rarer. It is more common in males. Osteolytic lesions are more common than mixed or purely sclerotic lesion. Radiologically, no definite characteristics are noted in any given situation. A mixed lytic and sclerotic lesion with a soft tissue swelling in a young person should suggest lymphosarcoma [22] (Figure 6).

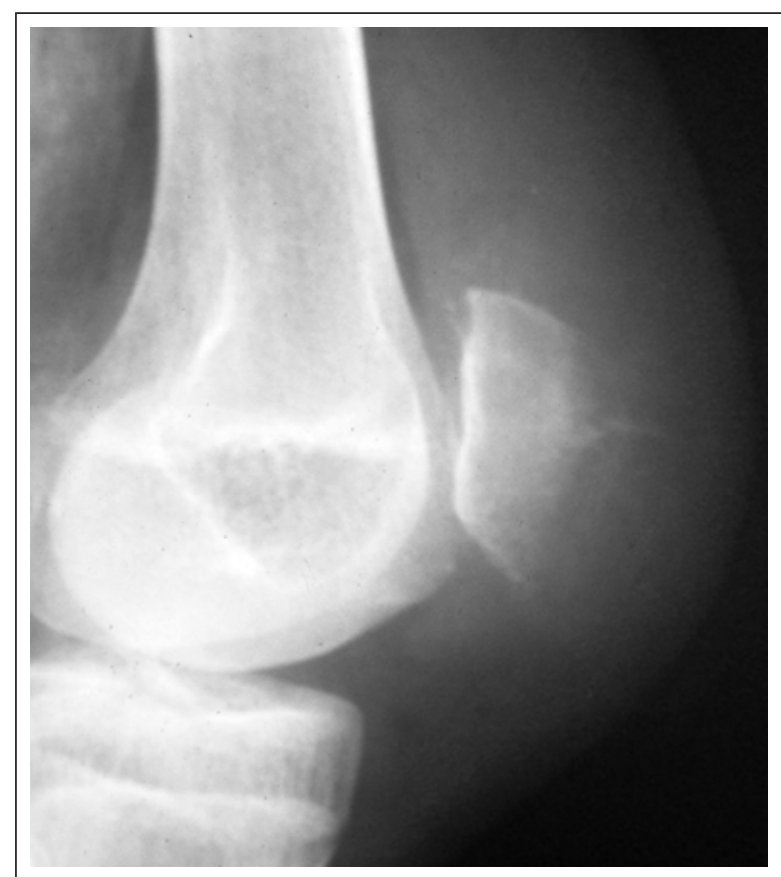

Figure 6: Lymphosarcoma in a 15-year-old boy. 
Solitary metastasis to patella is very rare. However, case reports have been published about metastasis arising from primary carcinoma of the breast and bronchus involving the patella. Metastatic lesions presented in order of frequency of primary tumors include breast, lung, prostate and kidney (Figure 7a, b). Radiologically while lytic, mixed and sclerotic lesions are common in carcinoma from breast, lung and kidney, sclerotic metastasis are more common in the carcinoma of the prostate. However, any primary in the body can metastasise to the bone [23]. In a solitary metastasis to the patella, it is difficult radiologically to diagnose without knowing the primary site of the lesion.
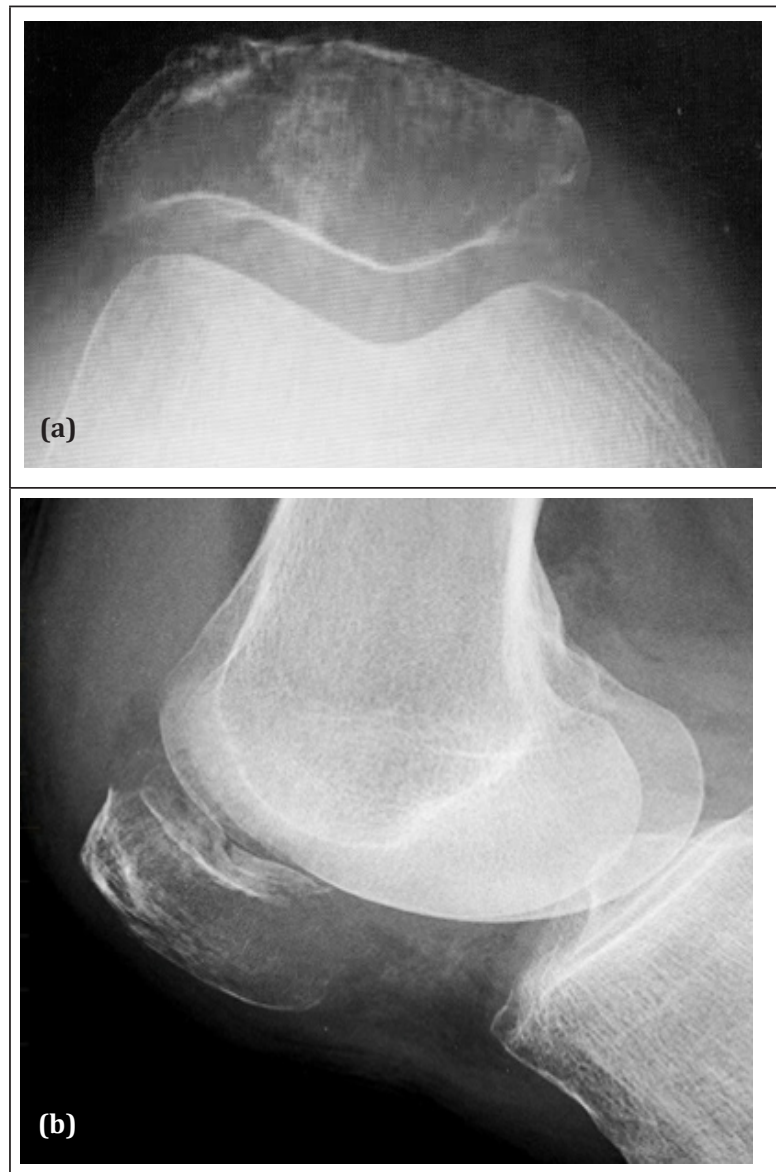

Figure 7a, b: Lytic metastasis from carcinoma breast

\section{Tumor like lesions}

$>$ Developmental

$>$ Traumatic

$>$ Infective

$>$ Osteonecrosis

> Metabolic - Gout, Hyperparathyroidism

$>$ Miscellaneous
In developmental abnormalities of the patella, bipartite and tripartite patella are relatively common. Bipartite patella is found in $2 \%$ of people. Bilateral involvement is noted in around $4 \%$ of people. Some authors consider that bipartite patella is probably traumatic [24]. Radiologically, these are located in the supero medial margin of the patella (Figure 8a, b).
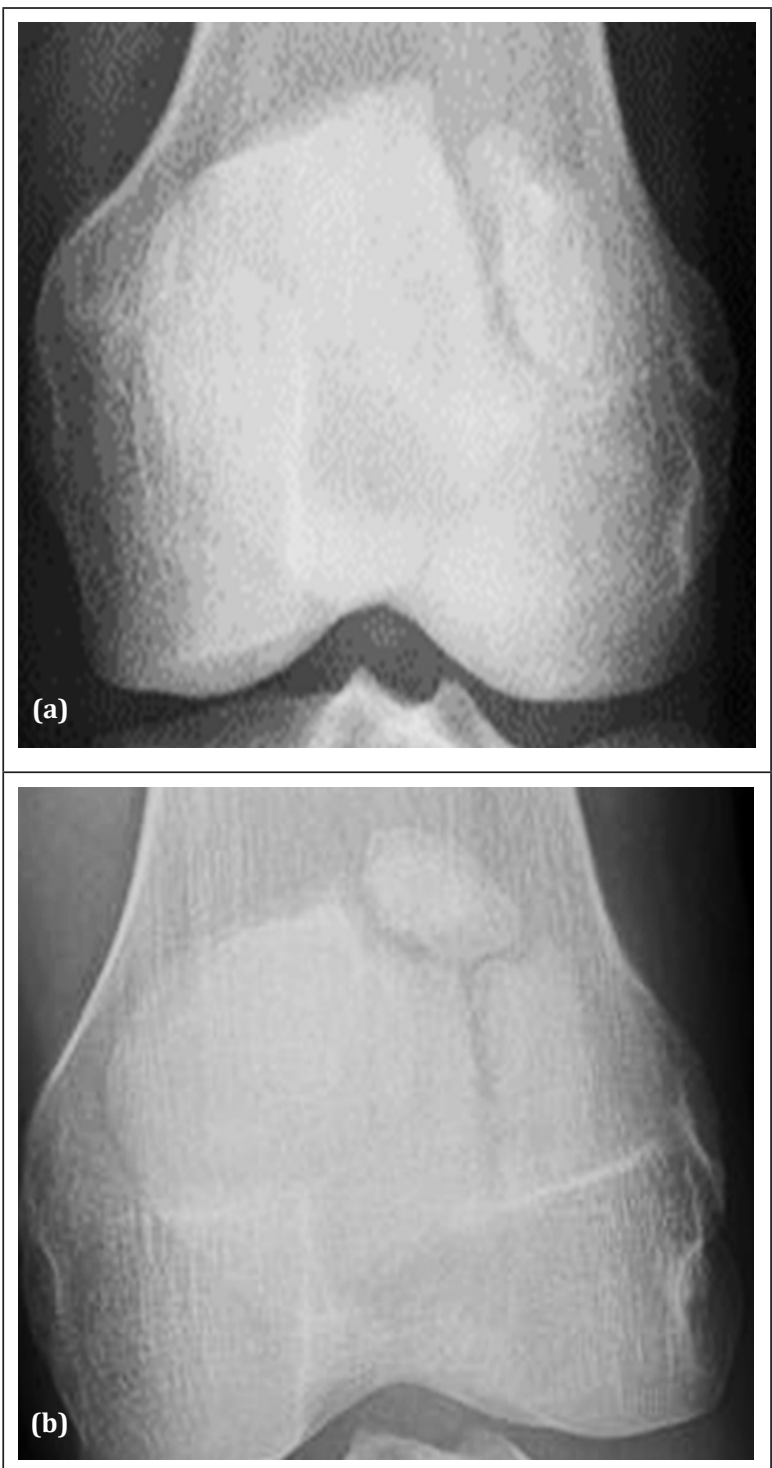

Figure 8a, b: Bipartite \& tripartite patella.

The dorsal defect of the patella (DDP) is a benign lesion with specific radiographic features. The characteristic lesion is round and lytic, with welldefined margins (Figure 9a, b, c). It is located in the superolateral aspect of the patella adjacent to the subchondral bone [25, 26]. Arthrography reveals intact cartilage. DD - Osteo chondritis dissecans. 

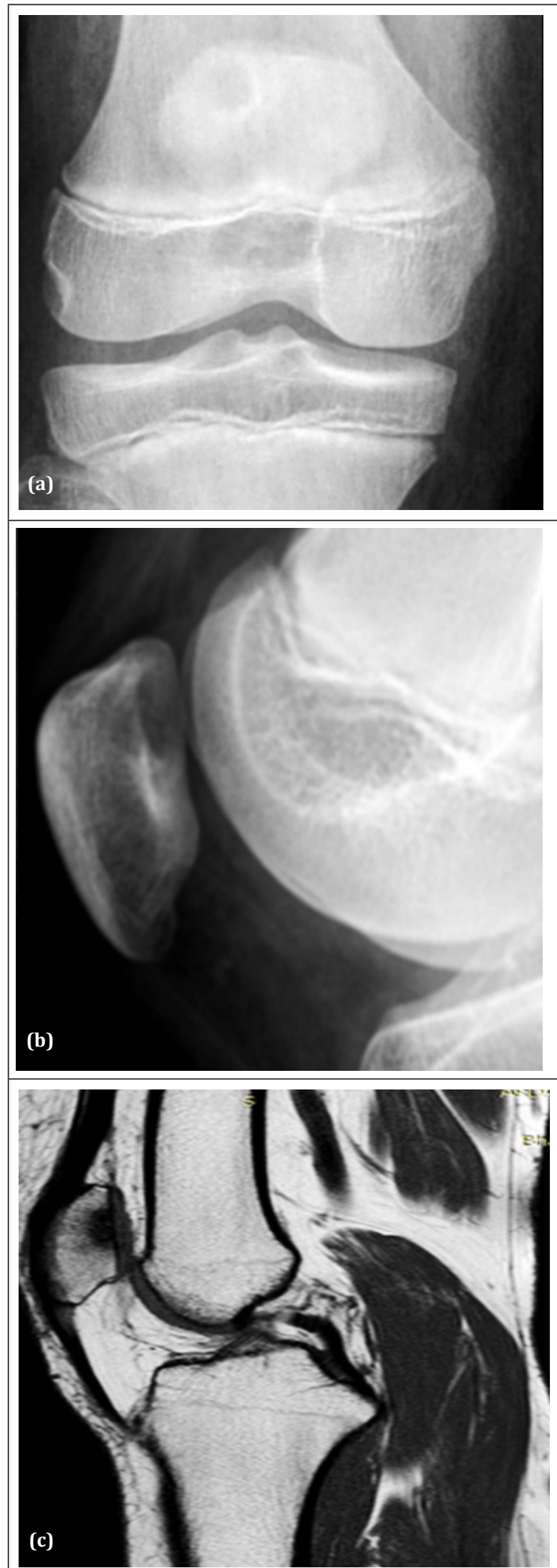

Figure 9a, b, c: Dorsal defect of patella; $(a, b)$ plain films, (c) MRI.

\section{Osteochondritis dissecans}

Most probable etiology includes direct or indirect trauma. Infection does not play a role. It is more common in medial femoral condyle, talus and capitellum of humerus. Radiologically, a lytic defect is noted in the articular margin of the patella with a loose ossified fragment [27] (Figure 10). MRI shows the relationship of the subcondral fragment to the underlying host bone and hyaline cartilage.

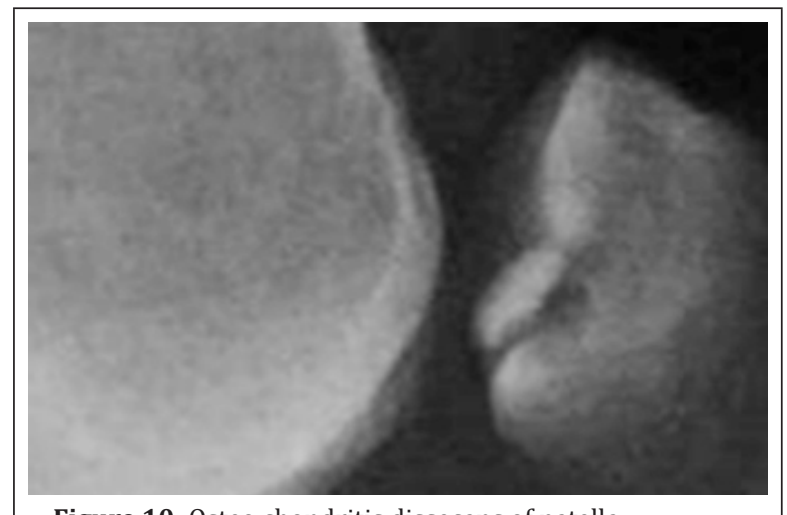

Figure 10: Osteo chondritis dissecans of patella.

\section{Infections of the patella}

Pyogenicosteomyelitis primarily involving the patella is rare. In septic arthritis of the knee, the patella may be involved and does not show any specific radiological characteristics (Figure 11a). Aspiration \& culture of the synovial fluid may show pyogenic organisms such as staphyloccal and other bacteria. Pyogenic osteomyelitis with brodie's abscess is also relatively uncommon [28]. Radiologically, a circular/ oval lytic area surrounded by reactive sclerosis is noted. MRI shows the penumbra effect (Figure 11b-f).

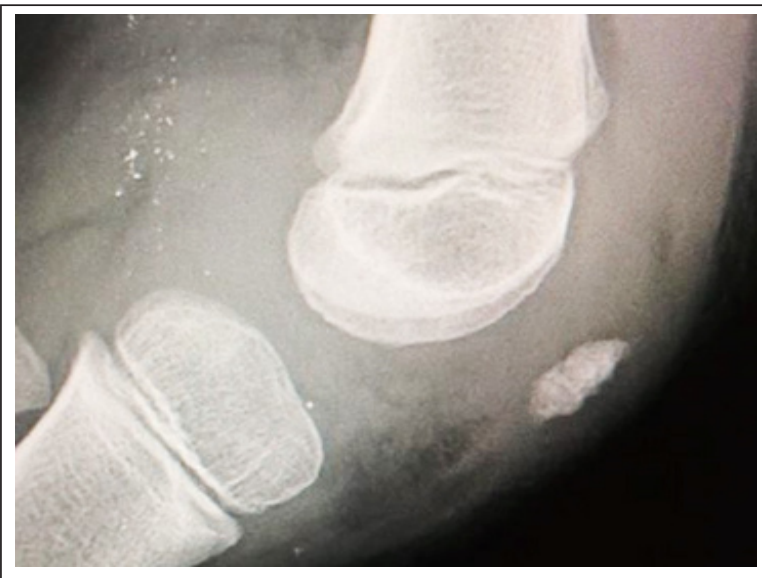

Figure 11a: Septic arthritis showing synovial effusion. 

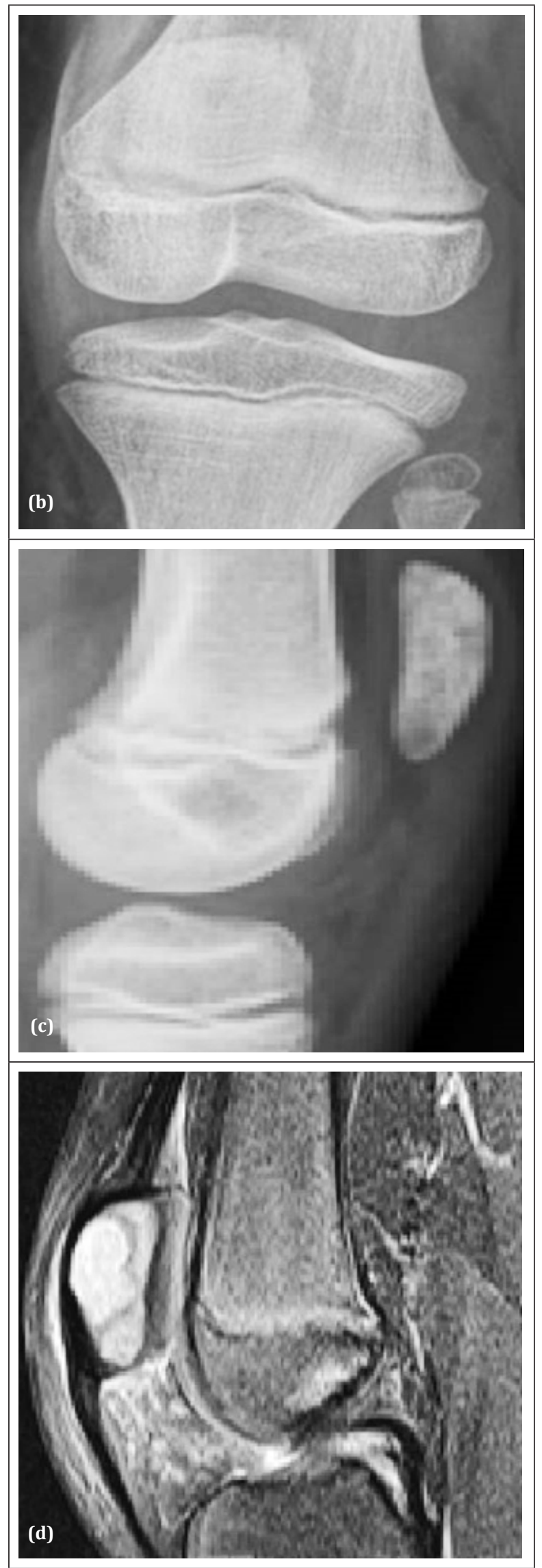
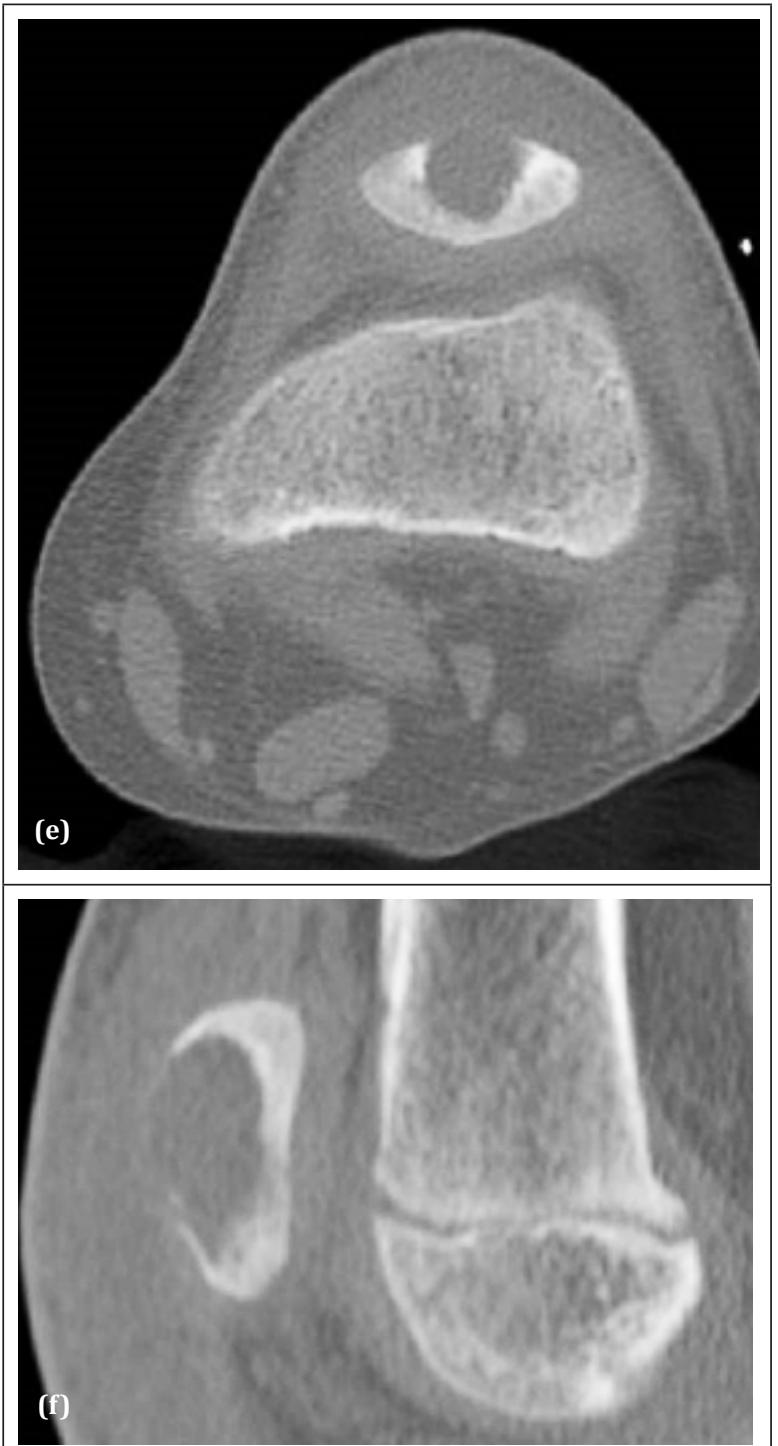

Figure 11b-f: Brodie's abscess in conventional, (d, e, f) MRI \& CT films.

\section{Tuberculosis of the patella}

Osteoarticular tuberculosis of the knee is not rare [29]. In skeletal tuberculosis, tuberculosis of the knee is encountered in about $10 \%$ of the time. Patella may be involved in this process. Radiologically, peripheral erosions of the articular margins with para-articular osteoporosis and synovial thickening characterise tubersulsois. The patella may show extensive erosions. Reactive bone is not a feature of tubercular arthritis (Figure 12a, b). However, isolated patellar tuberculosis is quite rare [30]. Radiologically, it may resemble Brodie's abscess with a lytic defect surrounded by sclerosis. MRI shows penumbra effect and may also show caseation with necrosis extending to the joint (Figure 12c, d, e). 

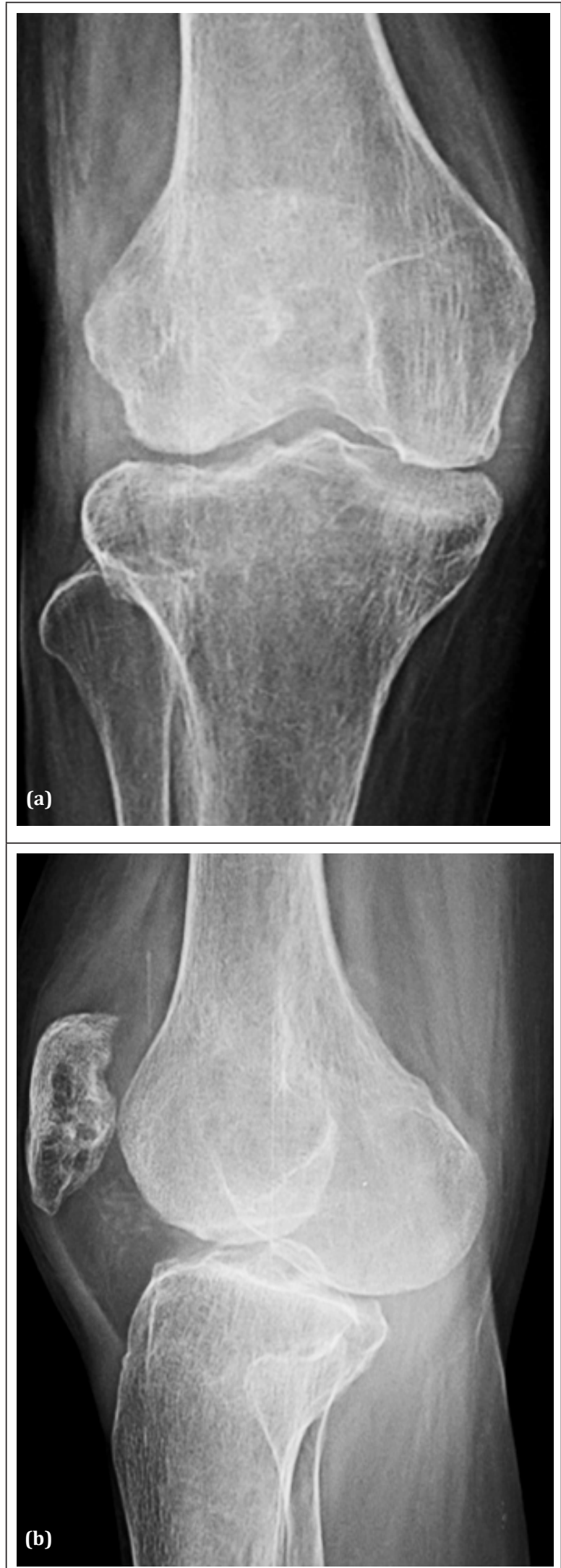

Figure 12a, b: Tuberculous arthritis of knee involving patella.
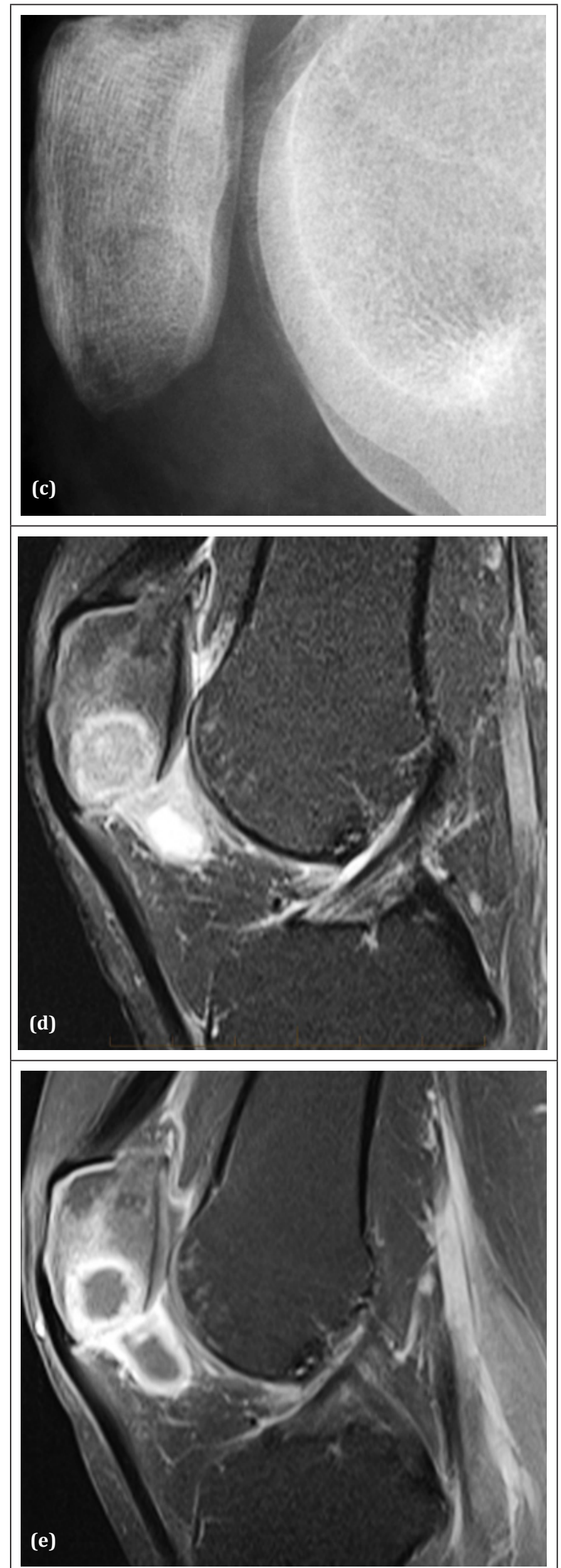

Figure 12c, d, e: TB abscess of patella; plain and MRI. 


\section{Osteonecrosis of the patella}

Osteonecrosis of the patella can occur in two locations of the patella, one superiorly and the second inferiorly. Several controversies exist regarding the etiology. A distinction is made between osteochondritis of the centre of patella or the primary nucleus (Kohler disease) and osteochondritis of the secondary ossification centre at the lower pole (Sinding-Larsen-Johansson disease - SLJ). Kohler disease can also refer to navicular avascular necrosis. The diagnosis of osteochondritis of the patella can only be made when the radiographic finding is definitely accompanied by clinical symptoms. It may be bilateral [31-33]. Osteonecrosis may be traumatic or iatrogenic due to steroid or radiation therapy. Radiologically, Kohler's disease shows increased density with fragmentation (Figure 13a), whereas in SLJ, the inferior pole of the patella is involved with fragmentation (Figure 13b, c).

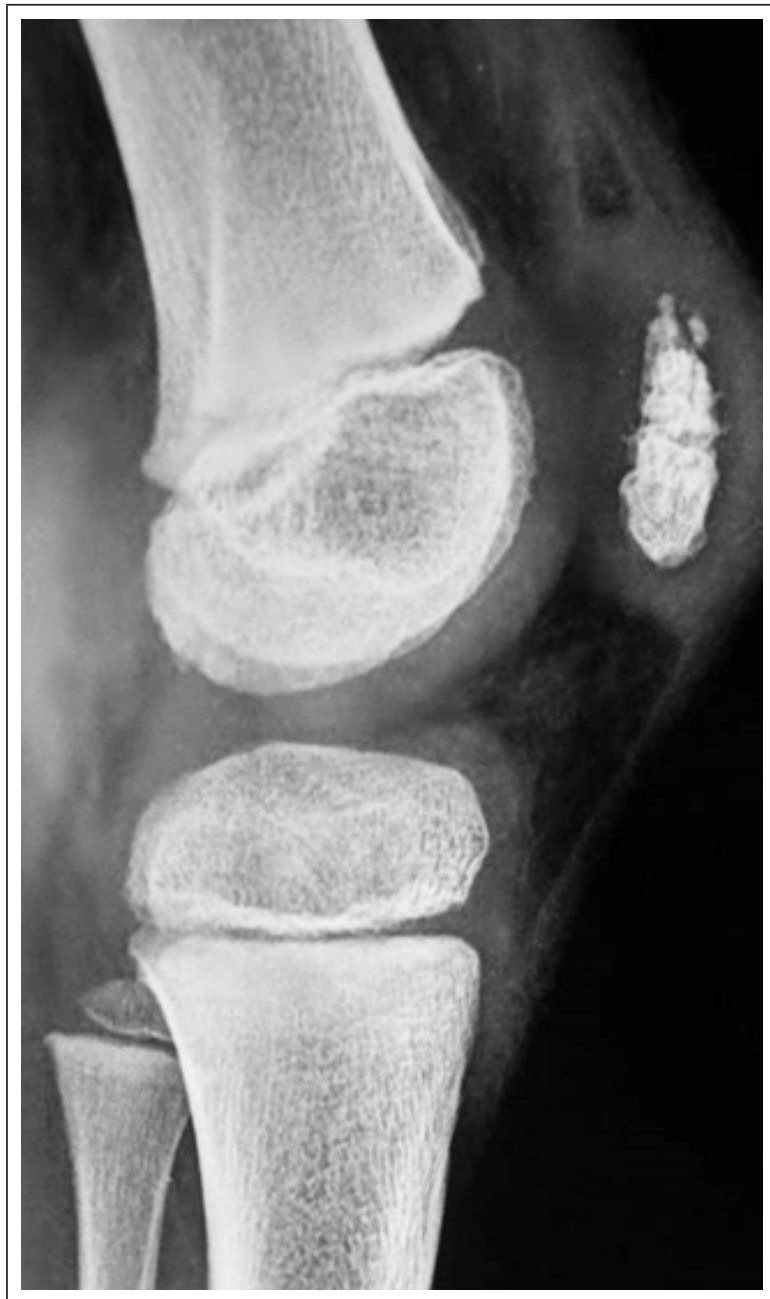

Figure 13a: Osteonecrosis of patella-Kohler's disease.
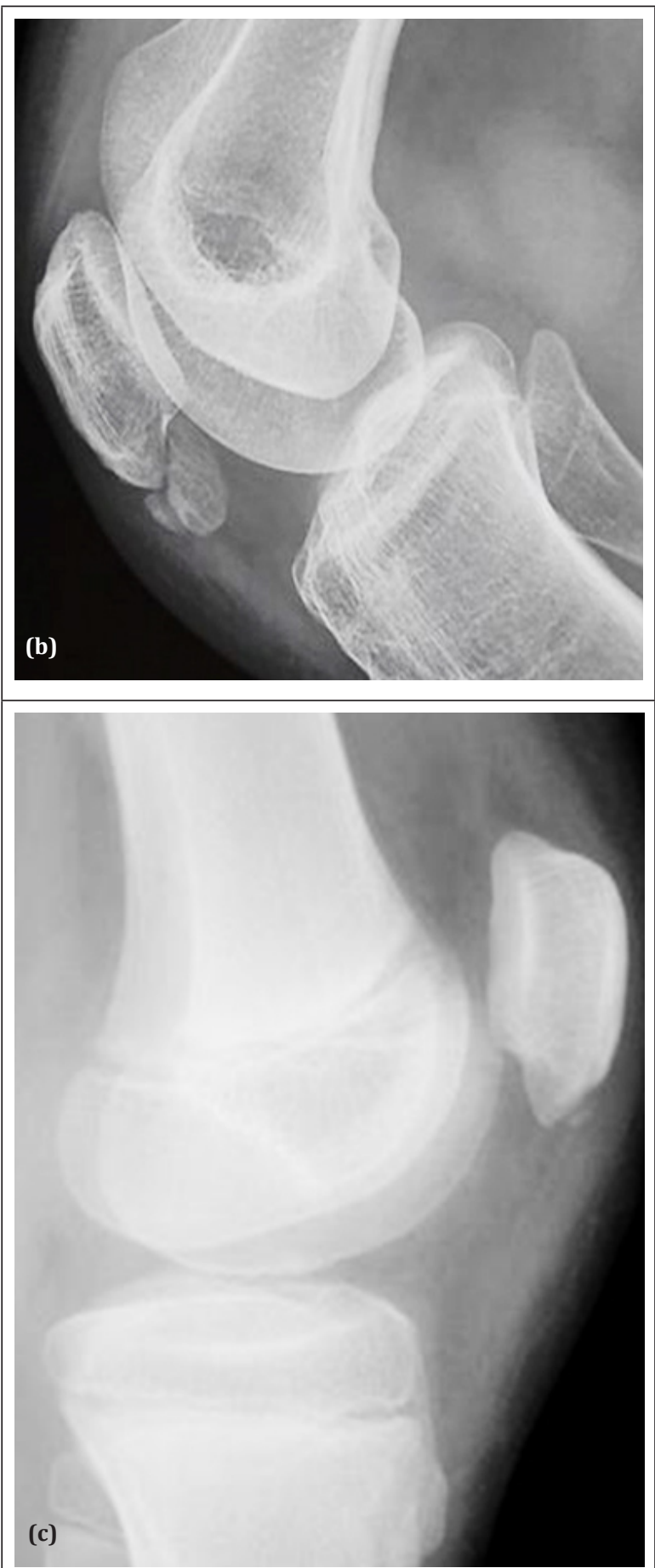

Figure 13b, c: Sinding-Larsen-Johansson disease.

\section{Gout of patella}

Gout is an inflammatory arthropathy caused by long-standing hyperuricemia. The first metatarsophalangeal joint is the most commonly involved joint, although gout is often polyarticular. Involvement of the knee is not uncommon, but involvement of the patella is rare $[34,35]$. Isolated 
involvement of patella in gout is extremely unusual. Radiologically, multiple lytic areas are noted with sclerotic margin, involvement of the knee joint renders a clue to the diagnosis (Figure 14).

\section{Brown tumors of hyperparathyroidism involving the patella}

Brown tumors which are localised lytic areas in bone with areas of fibroblasts and giant cells superimposed by hemorrhage. These are encountered commonly in long bones and jaws. These brown tumors are seen in both primary and secondary hyperparathyroidism. However, brown tumors involving the patella are rare [36]. Radiologically, marked osteoporosis and cortically oriented lytic lesions are noted (Figure 15). Clinical and laboratory data confirm the presence of hyperparathyroidism.
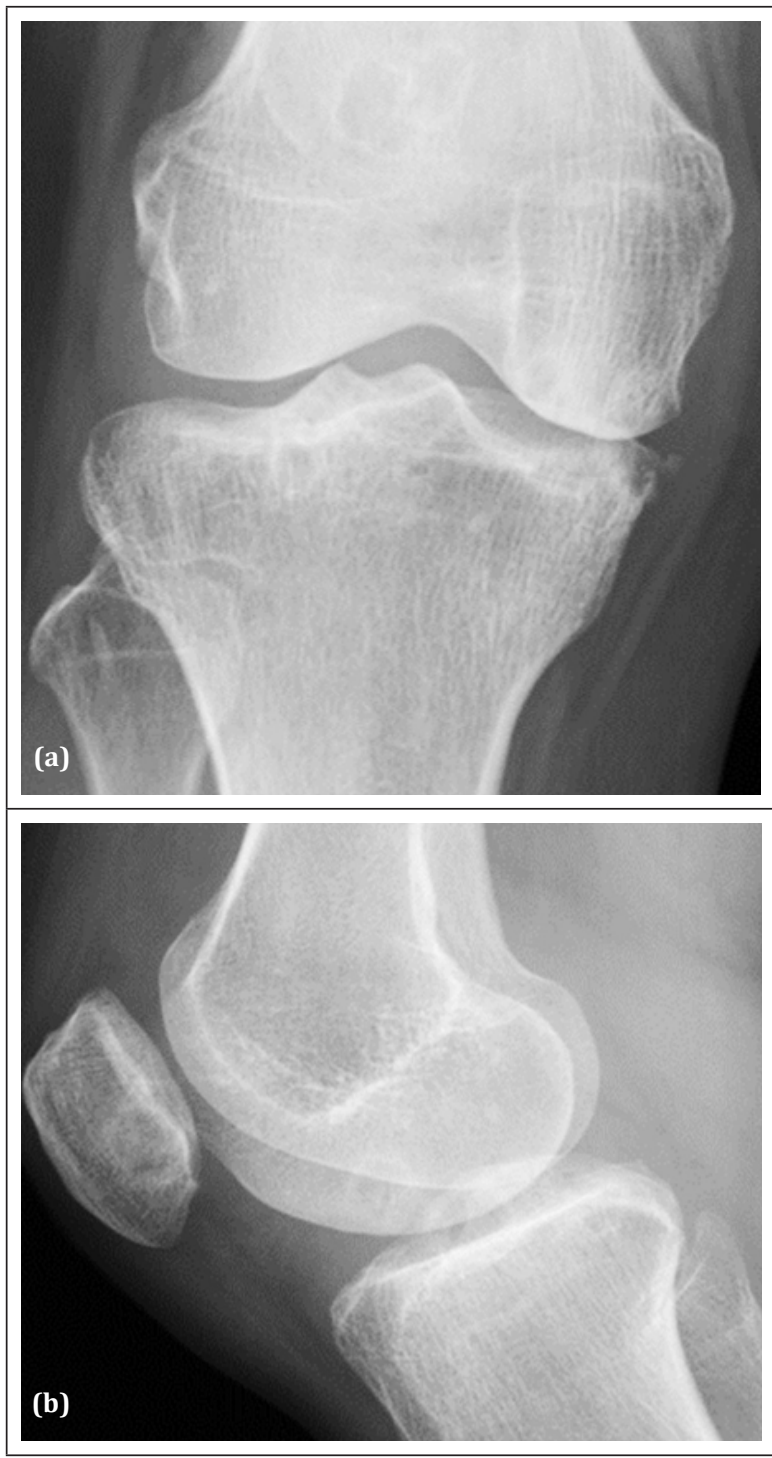

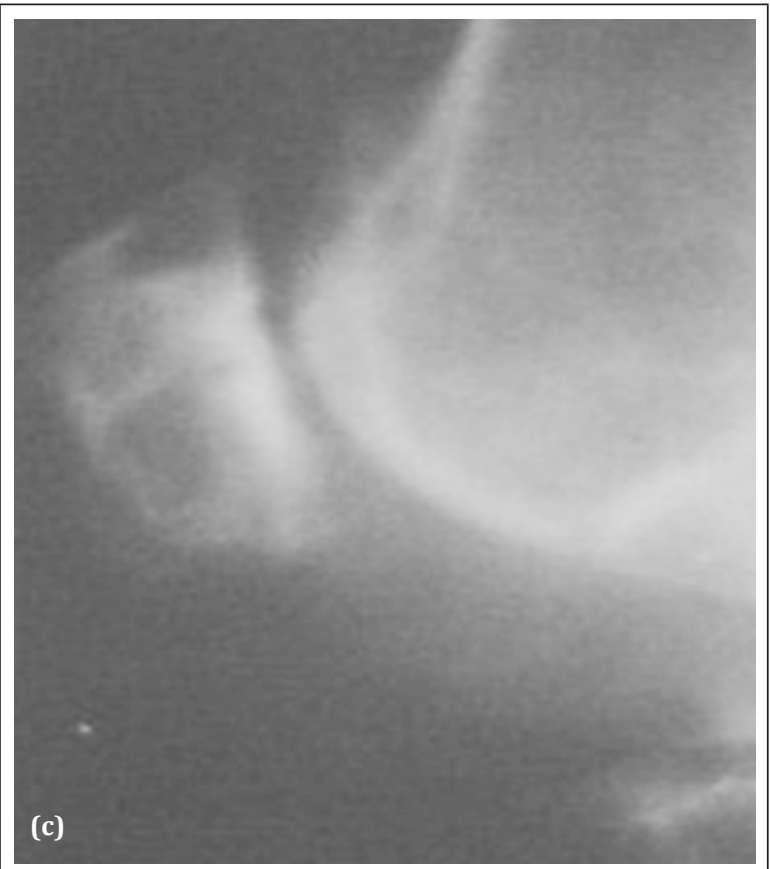

Figure 14a, b, c: Gout of knee joint and patella.

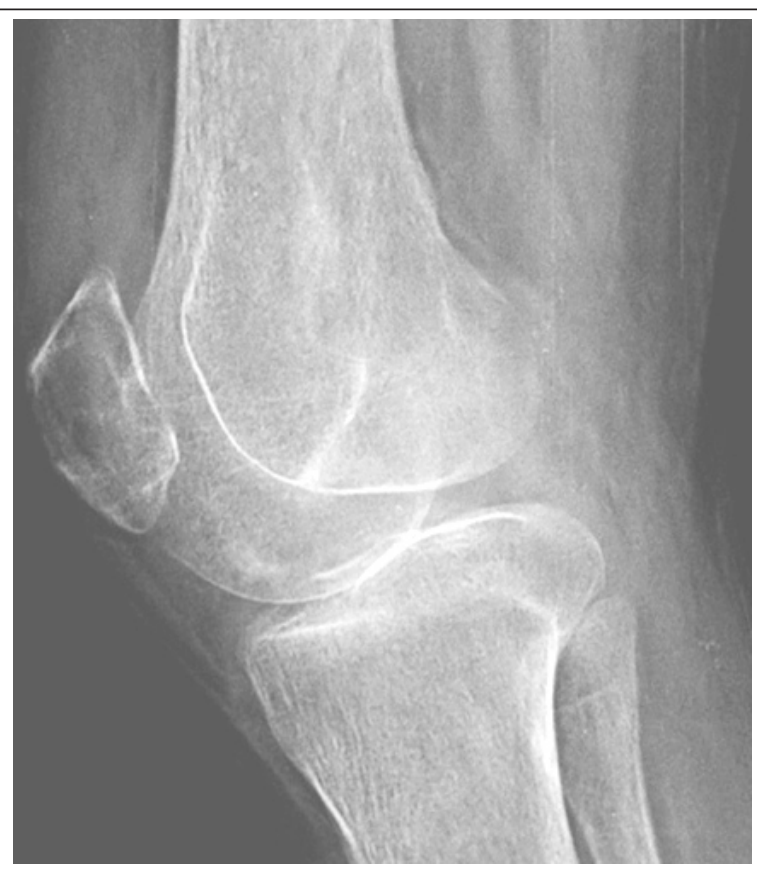

Figure 15: 34-years-old-female, brown tumor of patella in hyperparathyroidism.

\section{Paget disease of patella}

Paget disease of the skeleton is occasionally observed in India. Radiologically, 3 forms are noted: 1. Osteolytic, 2. Osteoblastic, 3. Mixed. The bones involved often include skull, spine, pelvis and long bones. Patellar involvement is quite rare [37, 38]. The appearances as indicated may be sclerotic, lytic 
or mixed type of lesions. Bones involved in Pagets are larger than usual and the process may extend to the articular margin (Figure 16).

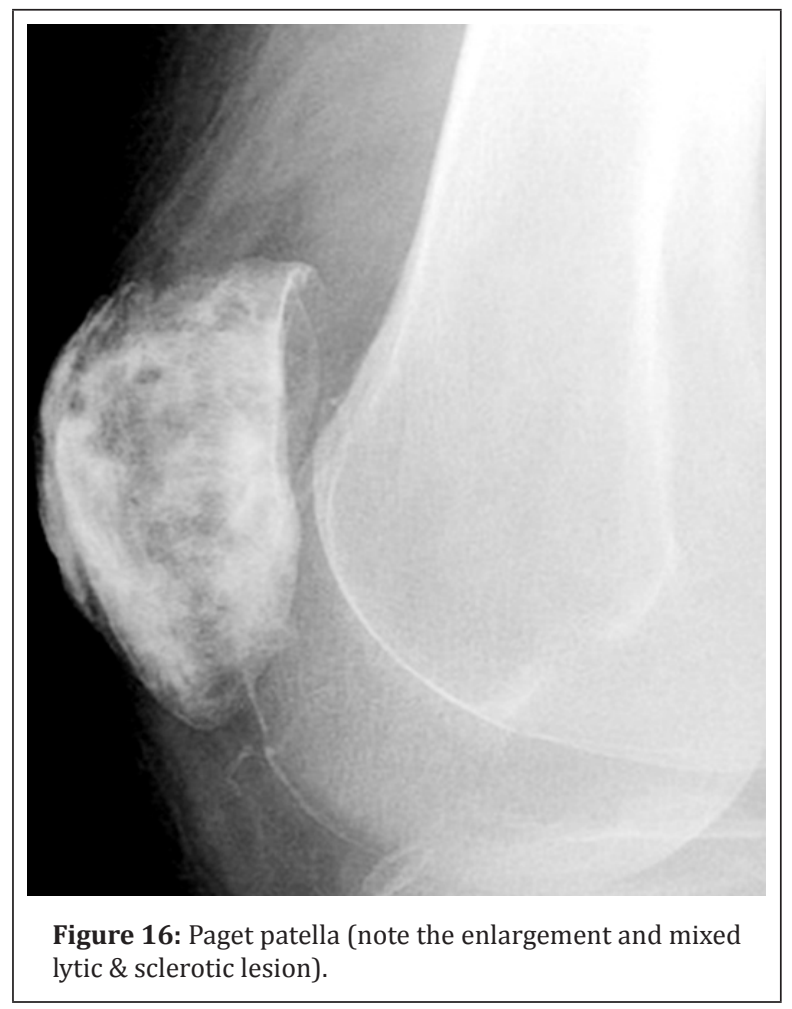

\section{Quadriceps tendinopathy \& patella}

The quadriceps tendon is attached to the patella. In degenerative arthritis as well as in diffuse skeletal hyperostosis, multiple osteophytes are noted in the superior \& anterior surface of the patella. Radiologically, this can resemble a dentate structure and hence called 'Tooth sign' [39]. Sometimes it may simulate whiskers and hence called 'whiskering'. These are best demonstrated in the skyline view of the patella (Figure 17).

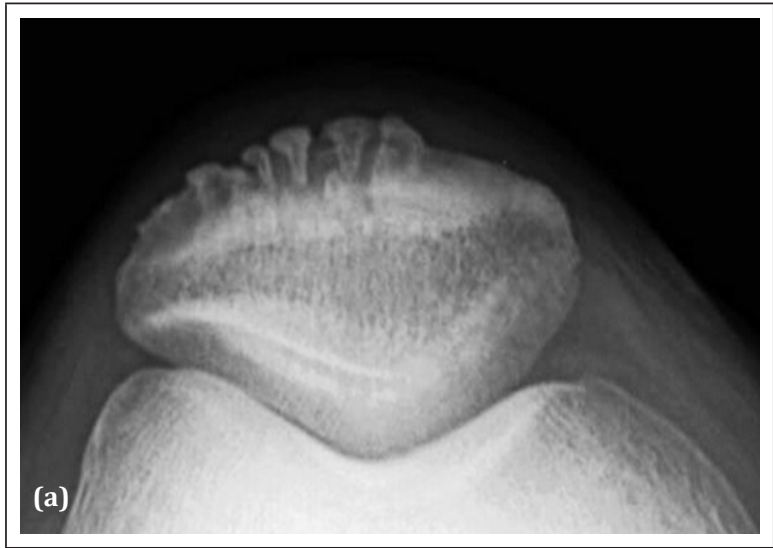

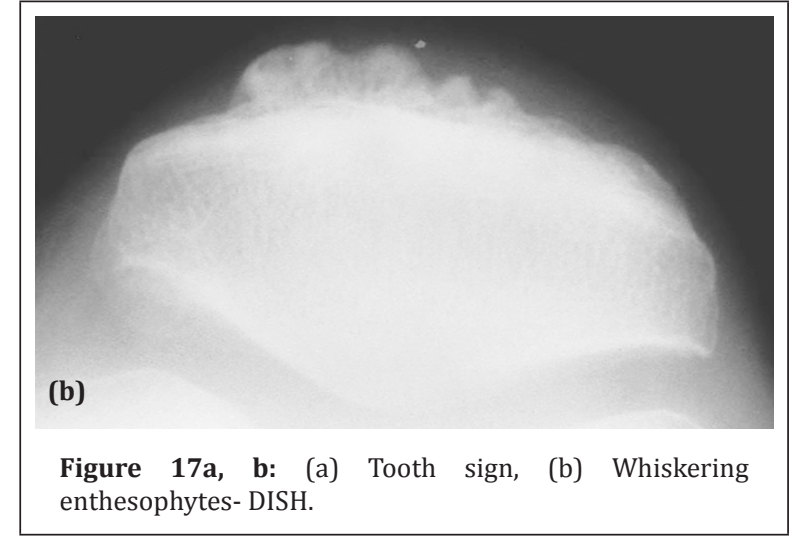

\section{Conclusion}

The patella is an uncommon location for neoplasms. The majority of tumors of the patella are benign, with a significant incidence of giant cell tumor and chondroblastoma. In our experience chondroblastoma seems to be more common. Radiological features are similar to the lesions at other sites. Tumor like lesions including developmental, infective, metabolic and of miscellaneous etiology are included in the differential diagnosis describing the radiological findings with the help of illustrations.

\section{Acknowledgements}

NIMS, KIMS, and KREST Museum, Hyderabad.

\section{Conflicts of interest}

Author declares no conflicts of interest.

\section{References}

[1] Song M, Zhang Z, Wu Y, Ma K, Lu M. Primary tumors of the patella. World J Surg Oncol. 2015; 13:163.

[2] Mercuri M, Casadei R, Ferraro A, de Cristofaro R, Balladelli A, et al., Tumors of the patella. Int Orthop. 1991; 15(2):115120 .

[3] Ferguson PC, Griffin AM, Bell RS. Primary patellar tumors. Clin Orthop Relat Res. 1997; 336:199-204.

[4] Kransdorf MJ, Moser RP Jr, Vinh TN, Aoki J, Callaghan JJ. Primary tumors of the patella. A review of 42 cases. Skeletal radiol 1989; 18(5):365-371.

[5] Singh J, James SL, Kroon HM, Woertler K, Anderson SE, et al. Tumor and tumor like lesions of the patella - a multicentre experience. Eur Radiol. 2009; 19:701-712.

[6] Pluot E, Steven MDA, James LJ. Tumors and tumor like lesions of the patella. Springer link. 2009; pp:637-646.

[7] Saglik Y, Yildiz Y, Basarir K, Tezen E, Guner D. Tumors and tumor like lesions of the patella: A report of eight cases. Acta Orthop Belg. 2008; 74(3):391-396.

[8] Dahlin DC, Unil KK. Bone tumors: General aspects and data on 8542 cases. Ed 4, Charles C Thomas, Springfield. 1986; pp:3-17.

[9] Unni KK. Dahlin's bone tumours: General aspects and data on 11,087 cases, 5 th edn. Lippincott-Raven. 1996; pp:463. 
[10] Ehara S, Khurana JS, Kattapuram SV, Rosenberg AE, elKhoury GY, et al., Ostelytic lesions of the patella. AJR Am J Roentgenol. 1989; 153(1):103-106.

[11] Moser RP Jr, Brockmole DM, Vinh TN, Kransdorf MJ, Aoki J, et al. Chondroblastoma of the patella. Skeletal Radiol. 1988; 17(6):413-419.

[12] Gudi N, Venkatesh Reddy VR, Chidanand KJ. Chondroblastoma patella presenting as a pathological fracture. Indian J Orthop. 2008; 42(1):100-101.

[13] Shibata T, Nishio J, Matsunaga T, Aoki M, Iwasaki H, et al. Giant cell tumor of the patella: An uncommon cause of anterior knee pain. Mol Clin Oncol. 2015; 3(1):207-211.

[14] Yoshida Y, Kojima T, Taniguchi M, Osaka S, Tokuhashi Y. Giant-cell tumor of the patella. Acta Med Okayama. 2012; 66(1):73-76.

[15] Wilson JS, Genant HK, Carlsson A, Murray WR. Patellar Giant Cell Tumor; Am J Roentgenol. AJR Am J Roentgenol. 1976; 127(5):856-858.

[16] Reddy NS, Sathi VR. Primary aneurysmal bone cyst of patella. Indian J Orthop. 2009; 43(2):216-217.

[17] Pevny T, Rooney J. Case report 876: Aneurysmal bone cyst of the patella. Skeletal Radiol. 1994; 23(8):664-667.

[18] Kransdorf MJ, Stull MA, Gilkey FW, Moser RP Jr. Osteoid osteoma. RadioGraphics 1991; 11(4):671-96.

[19] Bulas RV, Hayes CW, Conway WF, Loughran T. Case report 738: Osteoid osteoma of the patella. Skeletal Radiol. 1992; 21(5):326-329.

[20] Krishna Kumari S, Uma P, Vasavi HL, Kumar PL. Osteoblastoma of patella: A rare case. J Dr NTR Univ Health Sci. 2016; 5(4):291-294.

[21] McGrath BE, Schlatterer D, Mindell ER. Case reports: Osteogenic sarcoma of the patella spread to lateral meniscus after arthroscopy. Clin Orthop Relat Res. 2006; 444:250255.

[22] Cha S, Schultz E, McHeffey-Atkinson B, Sherr D. Malignant lymphoma involving the patella. Skeletal Radiol. 1996; 25(8):783-785.

[23] Gang Li, Changxing Shan, Ran Sun, Liu S, Chen S, et al. Patellar metastasis from primary tumor. Oncol Lett. 2018; 15(2):1389-1396.

[24] Lawson JP. Not so normal variants. Orthop Clinic North Am 1990; 21(3):483-495.

[25] Johnson JF, Brogdon BG. Dorsal defect of the patella: incidence \& distribution. AJR AM J Roentgenol; 1982; 139(2):339-340.

[26] Goergen TG, Resnick D, Greenway G, Saltzstein SL. Dorsal defect of the patella (DDp): a characteristic radiographic lesion. Radiology. 1979; 130(2):333-336.

[27] Desai SS, Patel MR, Michelli LJ, Silver JW, Lidge RT. Osteochondritis dissecans of the patella. J Bone Joint Surg Br. 1987; 69(2):320-25.

[28] Kankate RK, Selvan TP.Primaryhaematogenous osteomyelitis of the patella: a rare cause for anterior knee pain in an adult. Postgrad med J. 2000; 76(901):707-709.

[29] Mittal R, Trikha V, Rastogi S. Tuberculosis of the patella. Knee. 2006; 13(1):54-56.

[30] Goyal D, Sharma PK. Isolated tuberculosis of the patella: report of two cases and review of the literature. Bull Hosp Jt Dis. 2014; 72(3):237-241.

[31] Nicoletti D. Patella avascular necrosis (Kohler disease). Radiopaedia. 2017.

[32] Theodorou SJ, Theodorou DJ, Resnick D. Osteonecrosis of the patella: diagnostic imaging perspective. J Comput Assist Tomogr. 2005; 29(1):87-93.
[33] Theodorou DJ, Theodorou SJ, Farooki S, Kakitsubata Y, Resnick D. Osteonecrosis of the patella: Imaging features. Clin Imaging. 2001; 25(1):60-65.

[34] Clark S, Evans JM, Armstrong N, Schnitz W. Tophaceous gout with rare involvement of the patella. Radiol Case Rep. 2016; 11(4):380-385.

[35] Recht MP, Seragini F, Kramer J, Dalinka MK, Hurtgen K, et al. Isolated or dominant lesions of the patella in gout: A report of seven patients. Skeletal Radiol. 1994; 23(2):113-116.

[36] Irie T, Mawatari T, Ikemura S, Matsui G, Iguchi T, et al. Brown tumor of the patella caused by primary hyperparathyroidism: A case report. Korean J Radiol. 2015; 16(3):613-616.

[37] Olubaniyi BO, Howlett DC. Paget disease of the patella in a patient presenting with anterior knee pain. J Clin Rheumatol. 2014; 20(6):337.

[38] Hernandez-Pascual C, Villanueva-Martinez M, Rios-Luna A, Benito-del Carmen F, Castelorio R. Monostotic patellar Paget's disease; Acta Ortop Mex. 2010; 24(1):14-17.

[39] Weerakkody Y, Rezaee A. Patellar tooth sign. Radiopaedia. 